\title{
VIOLÊNCIAS "SUTIS": JOVENS E GRUPOS DE PARES NA ESCOLA
}

http://dx.doi.org/10.1590/1984-0292/1237

\section{Suzana Santos Libardi, Lucia Rabello de Castro ${ }^{\star}$} Universidade Federal do Rio de Janeiro, Rio de Janeiro, RJ, Brasil

\section{RESUMo}

Este trabalho trata das expressões "sutis" de violência que ocorrem entre os jovens na convivência em grupos de pares na escola. Foi realizada uma pesquisa empírica em duas escolas do Rio de Janeiro para conhecer os atos "sutis" de violência e qual a relação destes frente às normas da escola e as normas de convivência grupal - instituídas pelos próprios grupos de amigos. As análises dos resultados da pesquisa discutem o processo de naturalização das violências "sutis" e verificou-se que o revanchismo entre os grupos está intimamente relacionado às regras de convivência grupal e à inclusão ou permanência no grupo. A postura dos professores variou entre a negligência e a criminalização dos conflitos entre os estudantes, evidenciando como os adultos delimitam seus modos de intervenção junto aos jovens na escola hoje. Conclui-se que as possibilidades da geração mais nova de construir seu ethos de convivência se encontram severamente circunscritas à dinâmica de seu grupo de pares.

Palavras-chave: violência; grupo de pares; escola.

\section{"SubTLE" VIOLENCE: YOUNG PEOPLE AND PEER GROUPS WITHIN SCHOOL}

\section{Abstract}

The object of this work is the "subtle" expressions of violence that occur among young people living in peer groups within the school. A field research was carried out in two schools in Rio de Janeiro to know what these subtle acts of violence are and their relationship between the rules established by the school and the rules in grouping - instituted by their own groups of friends. The analysis of the results of this research discuss the process of naturalization of "subtle" violence and it has been noticed that the revenge between groups is closely related to simple rules for grouping and his/her inclusion or permanence in the group. It has been noticed that the posture of the teachers varied from neglecting to criminalizing these conflicts and tensions among students, showing how adults delimit their intervention on youth's social relations at school today. We can conclude that the possibilities that the young generation disposes of to construct their ethos of social conviviality is thought to be severely restricted to the dynamics of their peer group.

Keywords: violence; peer groups; school.

\footnotetext{
^Endereço para correspondência: Universidade Federal do Rio de Janeiro, Programa de Pós-graduação em Psicologia. Av. Pasteur 250 Pavilhão Nilton Campos - Urca. 22290240 - Rio de Janeiro, RJ Brasil - Caixa-postal: 56056.E-mail: suzana.libardi@gmail.com, 1rcastro@infolink.com.br
} 


\section{INTRODUÇão}

A violência é tema frequente nas pesquisas acadêmicas envolvendo jovens e tem sido habitualmente utilizada para identificar episódios de características diversas. Observamos que, no campo da juventude, a categoria da violência tem sido usada para classificar gama enorme de ocorrências distintas. Este procedimento contribui para o agigantamento do conceito e alimenta a sensação de que a violência alcança lentamente todas as esferas, camadas, instituições e relações interpessoais; multiplicando a sensação de insegurança da população. Mas do quê se trata exatamente a violência? Faz-se necessário não apenas definir o quê se entende por violência, mas também qualificá-la em seus aspectos constituintes, suas formas, manifestações; em intensidade, seus graus.

A relação entre juventude e violência vem sendo estudada por diferentes disciplinas como a sociologia, a pedagogia e a psicologia. O tema avançou por debates áridos, tais como: a compreensão da violência sendo ou não fundadora ou ameaçadora da cultura e da organização humana em sociedade (COSTA, 1986; MARIN, 2004; SOUZA, 2005; BIRMAN, 2009); os episódios de violência e sua relação com a pobreza (SPOSITO; TOMMASI; MORENO, 2009); a violência simbólica a qual os jovens estão submetidos no processo educativo (BOURDIEU, 2001; DEBARBIEUX, 2001; CHARLOT, 2002); as violências produzidas do lado de fora da escola, mas que de alguma maneira a atingem (CHARLOT, 2002; PINO, 2007; DAYRELL, J. et al., 2009); as violências que são produzidas na própria escola (CAMACHO, 2001; DEBARBIEUX, 2001; CHARLOT, 2002; DAYRELL, J. et al., 2009); a interferência da violência no processo de identificação dos adolescentes (LEVISKY, 2000), ou na construção do laço social e do processo de subjetivação dos jovens (FAGUNDES, 2004; GURSKI, 2012).

Neste trabalho, que contou com apoio da CAPES - Coordenação de Aperfeiçoamento de Pessoal de Nível Superior - , resultado de pesquisa para Mestrado em Psicologia, teve como objeto as expressões "sutis" de violência entre jovens, mais especificamente entre grupos de pares. A seguir, procuramos clarificar o que entendemos por violências "sutis". Posteriormente, apresentamos os resultados de pesquisa de campo realizada para conhecer tais episódios e qual a relação destas violências com as normas de convivência do grupo e as regras de convivência instituídas pela escola.

\section{Do Quê SE TRATA A VIOLÊNCIA, AFINAL?}

A diversidade de sentidos atribuídos ao termo violência (SOUZA, 2005; HOGEVEEN, 2007; PINO, 2007) se deve, entre outros fatores, à dificuldade de delimitar e definir precisamente do quê se trata a violência. Por se relacionar diretamente ao contexto social e cultural em que ocorre, o estudo sobre violência vem gerando definições tão díspares que dificultam a apreensão de quais ocorrências, de fato, esta categoria engloba. Um dos poucos consensos entre pesquisadores da violência é que o episódio considerado violento deve estar referenciado em 
determinada cultura e momento histórico. Partimos, então, da premissa de que a violência é fenômeno profundamente relacionado ao laço social e suas transformações ao longo dos tempos.

A violência da qual trata este trabalho é distinta da violência física; ou comumente nomeada por violência explícita (ALEXANDRE, 2006). A violência física, como o próprio nome diz, se refere às ocorrências onde um ou mais atores causam dano corporal a outra pessoa ou grupo(s) de pessoas. Trata-se de um tipo de dominação que se impõe atingindo o corpo e gerando dor física. Dentro do universo de trabalhos produzidos na pós-graduação no Brasil, pode-se dizer que a maioria das pesquisas sobre juventude e escola (DAYRELL et al., 2009) investiga o tema da violência corporal em suas variadas expressões comportamentais: empurrões, pontapés, brigas, murros, socos, chutes, espancamento, uso de armas brancas e de fogo.

Por outro lado, há outros tipos de situações que não produzem danos ao corpo, mas, ainda sim, devem ser consideradas violências. E o caso das violências implícitas. Na literatura (MARRA, 2007; STELKO-PEREIRA; WILLIAMS, 2010) se chama de violência implícita episódios nos quais um ou mais indivíduos prejudicam outro(s) por meio de comportamento discreto, velado, sem dano corporal. Há, portanto, um mecanismo de atingir o outro e prejudicá-lo sem necessariamente causar-lhe dor física.

A nosso ver, entretanto, considerar este tipo de violência como implícita pode dar a entender que ela é menos intensa. Acreditamos que o caráter implícito se refere apenas à forma como esta violência se expressa, implicitamente, e não ao seu grau de intensidade ou importância. Porém, tal nomenclatura pode sugerir uma minimização da autoria da ação: ela acontece de maneira acobertada e disfarçada. Por isso, acreditamos ser mais apropriado nomear tais episódios como "violências sutis", pois o termo contempla a forma tomada pela violência - velada, não explícita, sorrateira, não revelada - e expressa com precisão seu conteúdo de violência e de disfarce.

As diferenças entre casos de violência explícita e "sutil" se referem majoritariamente à maneira como a violência se concretiza, qual forma ela adquire e, a partir daí, às distintas classificações que cada uma recebe. Todavia, é comum no debate sobre os diferentes tipos de violência a pergunta sobre o quê precisamente torna esses episódios violentos, e, portanto, o quê é comum a essas ocorrências de manifestações variadas.

O traço comum seria o fato destes episódios causarem mal ao outro, independente da forma pela qual o fazem. A violência é um ato de fazer mal, de prejudicar, de causar algum tipo de dano a outra pessoa ou grupo(s) de pessoas. Além disso, nos atos violentos o mal é causado propositalmente. Ao contrário dos acidentes, que ocorrem sem intenção do autor da ação, a violência se caracteriza fundamentalmente pela ação de sevícia do autor com propósito de infligir um dano. Seja de maneira explícita ou "sutil", a intenção de aniquilamento ou desejo destrutivo são aspectos definidores para o ato violento (COSTA, 1986). Este trabalho se dedica às sutilezas da violência, uma violência que dispensa o uso da força física para sua definição e valoriza a capacidade de alguns atos produzirem danos - não-corporais, 
não-físicos, e sim de ordem moral, psicológica e simbólica. Partimos da ideia de que o(s) sujeito(s) da ação violenta não a fazem sem carregar seus atos com desejo de infligir sofrimento ao outro, conscientemente ou não (COSTA, 1986).

Esta perspectiva de que o ato violento é carregado de desejo (COSTA, 1986; FAGUNDES, 2004; BARUS-MICHEL, 2011; CAMPOS, P; CAMPOS, D., 2011) gera problemas para pensarmos seu reconhecimento. Ou seja, para reconhecermos a partir de que uma violência é claramente identificada. Se o desejo de causar mal ao outro é o definidor do ato violento, como reconhecer a violência nas trocas interpessoais diárias?

Autores, receptores e/ou observadores podem reconhecer a violência. Apesar de estes diferentes atores ocuparem lugares díspares na cena violenta, eles são igualmente importantes porque o lugar de cada um coloca desafios ao reconhecimento da violência. No que diz respeito à figura do autor, é o mesmo quem investe a ação com carga afetiva e a direciona para o aviltamento do outro. Ocorre que, muitas vezes, o desejo não está tão claramente acessível ao autor e, caso esteja, geralmente não se pode contar com seu depoimento confirmando-o - uma vez que tal confissão de dano se caracterizaria como produção de prova contra ele mesmo. Há também casos onde a violência está tão confundida com códigos relacionais e culturais que é tida como corriqueira, dirimindo a percepção do autor da sua responsabilidade pela violência.

Do lugar ocupado pelo receptor/vítima, a violência também é reconhecida quando ele se sente violentado, e percebe que o autor agiu com a finalidade de prejudicá-lo de algum modo. Neste caso, a vítima atribui desejo de destruição ao autor (COSTA, 1986). O observador da ação, por sua vez, ocupa o papel de um terceiro na cena violenta. Assim como o receptor, o observador identificará a violência quando atribui ao autor a intencionalidade de submeter a vítima (COSTA, 1986; CAON, 2005; BARUS-MICHEL, 2011). O sujeito "alvo" e o observador reconhecem a violência por alusão às condutas sociais legitimadas na cultura. A violência salta aos olhos justamente porque excede os hábitos do grupo social, ultrapassando seus limites. Este é um dos fatores que reforça a ideia da violência enquanto fenômeno cultural e, portanto, da necessidade de compreendê-la a partir de referências existentes no conjunto de relações sociais onde ocorre.

Nesta pesquisa nos debruçamos especificamente sobre a relação entre violência "sutil" e a convivência dos jovens em grupos de pares. Tomamos os grupos de pares como grupos de amigos da escola, pessoas mais próximas no ambiente escolar e com as quais os jovens passam mais tempo juntos. Trata-se de um grupo que compartilha experiências escolares cotidianas e reúne jovens de mesma faixa etária. Apostamos nesse recorte como uma forma de problematizarmos o laço social juvenil e a maneira como os jovens o constroem dentro da instituição escola.

Kehl, em A função fraterna (2000), lança luz sobre os mecanismos de construção do laço fraterno entre os jovens, especialmente no que tange aos aspectos subjetivos desse processo. Sustentada sob a noção de fratria - uma das formas de 
laço social na teoria psicanalítica (COUTINHO, 2009) - a autora trabalha o papel da irmandade na vida subjetiva, explorando a figura dos semelhantes, irmãos que supostamente se acham em uma posição horizontal de relações.

Para Kehl (2000), o papel dos irmãos e, nesse caso, semelhantes, é de amparo simbólico através da lei que fundamenta a organização social da comunidade fraterna. Os pactos que sustentam a relação entre os irmãos, e que garantem certa ordem à fratria, submetem todos seus membros às mesmas regulações. Neste sentido, cabe problematizar tais pactos: como os jovens hoje constroem os laços afetivos nos seus grupos? De que forma, e se, todos se submetem à mesma lei? E se não, como relatam suas dificuldades para fazê-lo?

Mapeamos as sutilezas da violência que aparecem entre os jovens na escola e discutimos em que medida a violência serve ou não à manutenção das relações entre pares. Expressões de violência evidenciam tensões no convívio diário entre os jovens. Elas sinalizam aspectos internos do próprio funcionamento de um grupo; ao mesmo tempo, também mostram como um grupo se diferencia de outros no tocante as suas filiações, identificações e sentimento de pertença. Apresentamos, em seguida, a discussão detalhada desses resultados.

\section{VIOLÊNCIAS "SUTIS": JOVENS NO CONTEXTO ESCOLAR E A CONVIVÊNCIA NO GRUPO DE PARES}

A pesquisa, de caráter qualitativo, se realizou com jovens do primeiro ano do Ensino Médio de duas escolas, uma pública e uma particular, localizadas na zona norte da cidade do Rio de Janeiro. O trabalho de campo nas escolas foi dividido em duas etapas.

Na primeira etapa utilizamos o método de observação-participante (CAMACHO; BELTRAME, 1999; MARTINS, 2005), durante as aulas dentro de sala, e também no tempo livre dos intervalos entre as aulas. Foram registrados no diário de campo as trocas dos alunos no cotidiano da escola, os movimentos dos grupos na hora do intervalo e, principalmente, alguns comportamentos supostamente violentos de ordem física ou não. Esta etapa do trabalho de campo permitiu um primeiro mapeamento das ações consideradas violentas entre pares; nos inseriu no cotidiano das escolas e possibilitou nossa aproximação com os estudantes. Nossa presença no dia a dia da classe diminuiu o estranhamento por parte dos alunos em relação à presença da pesquisadora (autora principal) e, com o passar do tempo, eles demonstraram se incomodar menos. Ao longo das observações foi possível mapear episódios que pareciam violentos ao olhar da pesquisadora o que foi útil na elaboração da segunda etapa do trabalho de campo. Por conta da convivência com os alunos foi possível "quebrar" algumas resistências e despertar o interesse deles pela pesquisa em curso, instigando-os a participar da segunda etapa - oficinas com alguns estudantes das turmas participantes da pesquisa.

Durante as observações envolvemos um total de 60 jovens; 30 de cada escola. Depois, convidamos os estudantes a participarem das oficinas. Procuramos incluir nas oficinas jovens da mesma classe, mas não necessariamente próximos, 
de modo que em cada escola tivéssemos um grupo participante das oficinas que refletisse o máximo possível a diversidade de grupinhos presente na turma inteira. Desse modo, contamos exatamente com 24 estudantes; sendo 12 de cada escola, nas duas oficinas realizadas em cada instituição. Os participantes foram nove garotas e 15 garotos, com idades entre 15 e 17 anos.

As oficinas se basearam na metodologia e perspectiva dos grupos de discussão sustentados na compreensão de Bleger (1980, p. 55) que trata o grupo como pessoas que "[...] tem objetivos, problemas, recursos e conflitos que devem ser estudados e considerados pelo próprio grupo". Interessou-nos então conhecer a perspectiva deste grupo em torno da questão das violências entre pares. Fomos às escolas motivadas pelas seguintes perguntas de pesquisa: quais episódios os jovens reconhecem como atos de 'violência sutil' em sua convivência grupal na escola? Quais são as relações destes episódios com as normas de convivência grupal? E o que dizer das 'violências sutis' perante as regras instituídas da escola?

O processo de análise enfrentou primeiramente a extensão de falas advinda das transcrições das oficinas. A imersão nas narrativas permitiu, filtrar aquilo que se relacionava especificamente com nossas perguntas. Apresentamos a seguir os resultados organizados em três eixos analíticos, a saber: 1) a naturalização das violências entre pares; 2) a violência e as normas de convivência em grupo; 3) a violência entre pares versus as regras da escola. Este último foi o único eixo que apresentou diferenças significativas entre a experiência de estudantes das escolas pública e particular.

\subsection{A naturalização das violências entre pares: limites sutis entre brincar e maltratar}

No início da primeira oficina, percebemos resistência dos jovens se descolarem da ideia de violência como ato de agressão física, exclusivamente. Inicialmente eles indicaram apenas conflitos físicos - murros, socos, brigas - como formas de violência envolvendo alunos. Foi necessário o uso de casos fictícios (inspirados no mapeamento feito anteriormente) para estimular o debate entre os participantes. Os casos exemplificavam algumas ocorrências que, apesar de não serem agressões físicas, se concretizavam como atos de violências. A partir desses casos os jovens começaram a discutir outras possibilidades de a violência se apresentar. Com o avançar da discussão eles chegaram à conclusão de que as ações presentes nas histórias são atos que machucam o colega, apesar de não causarem dano físico.

Superado este momento, os grupos trouxeram outras formas de conflito entre colegas e a existência de formas não físicas de violência entre eles. Os dois grupos envolvidos na pesquisa indicaram algumas "brincadeiras", como apelidos jocosos e algumas formas de tratamento - a maneira de se referirem ao colega, de chamar a sua atenção - como manifestações da violência "sutil" no dia a dia escolar. Nas oficinas, os jovens relataram a presença cotidiana destes comportamentos como maneira de eles se relacionarem uns com os outros.

No início da tarefa, os grupos indicaram tais episódios como algo engraçado e como uma maneira de fazerem piada uns com os outros. "É apenas uma brincadeira", repetiam. Mas, a medida que eles passaram a discutir o porquê das 
brincadeiras depreciativas, alguns participantes foram dando outras respostas e o grupo foi elaborando outras análises para a situação. Neste momento eles não se limitaram aos casos fictícios, e todos os episódios foram avaliados pela sua carga pejorativa e sua capacidade de causar dano ao outro, mesmo que através do riso. Presenciamos uma ocorrência deste tipo quando um aluno usou de ironia para dizer que um colega estaria "saindo do armário" ao expor publicamente sua orientação homossexual. Foram relatadas como frequentes algumas formas de tratamento, por exemplo: "Ô F., seu viado, me empresta o MP3". Alguns jovens participantes trouxeram elementos para tentar aliviar o tom pesado das "brincadeiras", mas a grande maioria afirmou o poder de magoarem o colega e que, na maioria das vezes, as "brincadeiras" desqualificam a imagem deste colega diante da turma.

Nas falas dos estudantes, a violência acabou sendo elaborada como "qualquer coisa que magoe", "que magoe por fora ou por dentro", "qualquer coisa que agrida moralmente ou fisicamente". Eles falam, então, de uma noção de violência que engloba episódios que não usam força física. No trecho que se segue um participante fala da violência "sutil" a qual nos referimos neste trabalho:

[violência é] Usar palavras que machuquem a pessoa. Na hora você pode nem bater... Nem precisa bater na verdade. Vamos pra uma situação hipotética. É feito aqueles repentes que têm no nordeste: um explora os defeitos do outro. Você é baixo, você é isso ou aquilo. Aí quando o cara fala isso pra você, você responde a ele com os defeitos dele. É a mesma coisa. Nem precisa ser através de violência... física, digamos assim. É você explorar o defeito [...] (Bruno, ${ }^{1}$ estudante da escola particular, 15 anos, grifo nosso).

Neste sentido, as “zoações" entre os estudantes seriam exemplos de violência porque, mesmo sem a força física, magoam, causam dor, injúria, maltratam, provocam algum tipo de dano, prejudicam, desmoralizam.

Durante nossa estada na escola pública e na escola particular, as violências dos apelidos/"brincadeiras"/formas de tratamento, mesmo "machucando a pessoa", dificilmente despertavam alguma reação do colega ou alguma intervenção do professor. Durante as oficinas os participantes descreveram episódios que os magoaram profundamente, mas naquela situação eles não ousaram responder de qualquer maneira que fosse. Ficou claro que, do lado de quem é motivo de riso, a resposta mais frequente às "brincadeiras" é o silêncio.

Isto ocorre porque os atos de violência que não é física, as violências "sutis", compõem o cenário cotidiano das escolas. E no caso das escolas participantes da pesquisa estas violências "sutis" parecem não causar mais estranhamento à maioria dos atores do cotidiano escolar. A violência então se torna natural, é direcionada para o campo das coisas que não podem ser mudadas, que não podem ser repensadas justamente porque "são como são". A naturalização da violência se refere aos processos pelos quais as relações violentas passam a atravessar as 
trocas interpessoais cotidianas e compor os códigos relacionais dos atores envolvidos - como ocorreu também em pesquisas realizadas em escolas argentinas (BRINGIOTTI; KRYNVENIUK; LASSO, 2004).

O processo de naturalização, todavia, não faz com que as experiências violentas deixem de produzir desconforto. Acreditamos que a naturalização contribui para a ausência de reações frente à violência infligida, buscando minimizá-la. Daí pode resultar o arrefecimento de se estranhar tais situações. Os jovens participantes da pesquisa, por exemplo, disseram estar acostumados a estes episódios, banalizaram os atos "sutis" de violência e acharam, até, que são naturais na relação entre pares. Talvez por isso eles se acostumem a não reagir imediatamente às formas de tratamento que os ridicularizam, aos apelidos jocosos e às "brincadeiras" de mau gosto.

Naquele momento das oficinas, problematizamos as brincadeiras jocosas que costumam não despertar reação. $\mathrm{O}$ quê as diferencia da violência? Quais "brincadeiras" seriam realmente apenas brincadeiras, ou seja, motivo de riso que não prejudicaria o outro? Para sair desta encruzilhada eles escolheram o critério da intencionalidade. Ou seja, haveria violência quando há intenção de prejudicar o colega.

É muito fácil saber quando é brincadeira e quando não é.
Quando não é, a pessoa tem intenção de te magoar, e isso é
muito fácil de se perceber. No olhar você já sente. Vou dar
um exemplo: quando me chamam de 'anão'. Ah, eu não ligo
muito, sabe? Eu saco quando é de onda ou não. Quando
é uma brincadeira, você pára quando o outro pedir. Quando
você tá fazendo de maldade, aí você continua até a pessoa
estourar. Você faz justamente pra isso, na verdade (Bruno,
estudante da escola particular, 15 anos, grifo nosso).

O trecho da fala de Bruno explicita a ideia de que uma "zoação" pode ser apenas uma brincadeira nos casos onde não há desejo de aviltar o outro. Nestes casos, parece haver uma margem até onde se pode brincar com o colega sem, supostamente, agredi-lo. Já nos casos onde a intenção de magoar está disfarçada pela brincadeira, limites são propositalmente ultrapassados e, com este ato, caracteriza-se violência "sutil". É importante destacar que o autor da ação não confirma necessariamente a intenção de fazer mal, mas quem está sendo "zoado" o faz. O indivíduo que é objeto da "brincadeira" atribui ao outro a intenção de feri-lo ou magoá-lo. Assim, para os jovens, a atribuição de intencionalidade delimita fronteiras entre brincadeira e violência "sutil.

Percebemos que as "brincadeiras" são usadas para testar os limites do colega. Bruno explicita isso quando fala da intenção proposital de testar e ultrapassar os limites do outro, manipulando tais tensões. O uso destas "brincadeiras" foi muito frequente durante as observações realizadas nas escolas. Elas contêm o elemento específico de "fazer rir" mais. É como se o jogo que 
testa os limites do outro "tivesse mais graça" do que as brincadeiras que não desestabilizam o outro ou que não testam seus limites. O prazer decorrente da brincadeira apareceu diretamente ligado a esta tensão.

Observamos que o brincar nestas situações desperta maior atenção dos jovens quando entrelaçado ao gozo pelo constrangimento do outro; como se a violência "sutil" apimentasse as "brincadeiras" juvenis, tornando-as mais prazerosas.

Quando os jovens brincam com zoação, também testam os limites da brincadeira. Manejando a tolerância do outro, eles manipulam o lúdico e sua fronteira com o agressivo. Ocorre, todavia, que os limites não estão claramente postos. As "brincadeiras" se desenrolam na fronteira entre ludicidade e violência (FAZZI, 2004), exigindo que os atores envolvidos manipulem estes vieses a todo o momento. O espaço dos jovens corresponde a uma margem na qual eles "zoam" o colega, e, ao mesmo tempo, quase o ofendem. Esta margem produz então certa imprevisibilidade do quê a "zoação" pode produzir entre eles quando estão na escola.

De um modo ou de outro, tratando-se de brincadeira ou machucando o colega, o potencial agressivo da "zoação" só pode ser confirmado depois do fato acontecido. Apenas a posteriori uma brincadeira será vista como tal, ou dará espaço para ser vista como ofensa. Isso nos leva a crer que ao brincar de testar os limites do outro, não há forma segura dos jovens anteverem os efeitos que tal "brincadeira" pode causar. Ela pode ser minimizada por quem é "zoado" e, talvez, não acarretar maiores consequências (pelo menos aparentemente), ou gerar problemas, caso seja percebida como agressão - o que também acontece do ponto de vista dos observadores. O fato é que nem mesmo aquele que "zoa" o colega tem controle das reações que podem decorrer. $\mathrm{O}$ aspecto da imprevisibilidade se constitui como um elemento importante para a convivência entre pares, especialmente porque essa dinâmica acontece veloz e repetidamente no cotidiano da escola.

No ritmo das trocas diárias, os jovens vão testando os limites dos colegas, definindo até onde vai a "brincadeira" e vários participantes das oficinas destacaram que há limites para tal. Quando convocados por nós a definir tais contornos eles disseram haver dificuldade que "uma brincadeira se torna séria quando 'o outro' não está brincando" (Rodrigo, estudante da escola particular, 15 anos). "Mas como saber se o outro está ou não brincando?", perguntamos ao grupo. Os dois grupos participantes pareceram concordar que a "brincadeira" pode virar coisa séria a depender de quem está brincando e de qual tipo de brincadeira está em cena.

Avançamos mais nas oficinas continuando com nosso questionamento "como distinguir uma brincadeira de uma violência". Os jovens depositaram mais peso no critério de quem está envolvido na brincadeira, ou seja: o nível de proximidade que há com quem faz a brincadeira. "Depende da pessoa que tá brincando", disseram alguns. Para eles, quando se está entre amigos as "zoações" são encaradas como meras brincadeiras. Com colegas mais chegados, ou amigos mais próximos, se pode esticar limites e "zoar" sem tanta preocupação. Assim, a intimidade seria o critério mais importante para autorizá-los a "zoar" o outro. Quanto mais amigo, mais tolerável o "brincar". "Depende também da intimidade das pessoas, né? Se é amigo é tudo mais de boa e tal" (Thiago, estudante 
da escola particular, 16 anos). Quando existe amizade fala-se em brincadeira, uma vez que a amizade parece ser um contrapeso para o aviltamento gratuito; caso contrário, reconhece-se, então, a violência ou agressão.

Há um aspecto relevante a ser destacado: o laço de amizade por si mesmo não dá permissão para "zoações", mas para reciprocidade. A intimidade lhes permite manipular o lúdico e a agressão, porque é sabido que o colega que ri poderá também ser "zoado" a qualquer momento. Os laços de amizade servem como condição que os possibilita a partilhar deste jogo de forma recíproca.

Se eu zoar o Thiago e ele aceitar a zoação e me zoar de volta, aí é brincadeira. Agora se eu sei que uma pessoa é metida, e ela não é minha amiga e eu vou gastar ela na frente de todo mundo, eu sei que ela não vai aceitar e brincadeira e eu sei também que ela não vai revidar, entendeu? Tem exemplos aqui na sala. Então é assim. Quando há reciprocidade eu acho que é brincadeira, e quando não há aí é outra coisa [...] mais séria (João Paulo, estudante da escola particular, 15 anos, grifo nosso).

Faz parte da vida isso fêssora! [risos de todos os presentes] Porque pô, quer só vencer, vencer, vencer, uma hora vai ter que perder ué! Num tem aquele ditado? "Num dia a gente apanha, no outro dia a gente bate", "Um dia é da caça, o outro do caçador"? (Daniel, estudante da escola pública, 16 anos, grifo nosso).

Parece então que a diversão não produzirá desentendimentos quando se antecipa uma próxima vez em que a "zoação" poderá ser feita com o colega que está "zoando" hoje, na melhor das hipóteses. Daniel recorre inclusive a ditos populares que apresentam a reciprocidade como um movimento natural, regra pela qual o amigo sabe que também o autor poderá ser motivo de riso. Sabemos, no entanto, que nem sempre isto ocorre, já que a presença de marcadores de desigualdade social, o diferencial de assertividade e poder entre amigos (dentre outros aspectos) explicaria porque uns são mais zoados do que outros.

Até aqui os jovens reconheceram a presença de violências "sutis" na sua convivência dentro da escola e identificaram algumas "brincadeiras" como exemplos desse tipo de violência. Eles elencaram alguns elementos que minimizam o poder de dano da "zoação", fazendo-a se distanciar daquilo que reconhecem como violência: a atribuição da intenção de maltratar ao autor da ação e a existência de uma relação de amizade com o autor da "brincadeira". De nossa parte, cabe pensar mais sobre este último elemento. O quê esta escolha pode nos dizer?

A amizade permite que diversos tipos de "zoação" sejam utilizados. Mesmo que gere desmoralização, os apelidos ou formas jocosas de tratamento são usados, desde que empregados apenas para fulano e cicrano - os amigos, os pares. Para os participantes dos grupos da pesquisa, mesmo que o jovem reconheça 
na brincadeira do grupo de pares alguma má intenção, a "violência sutil" é minimizada. Essa é, no entanto, reconhecida, quando provém de uma figura que não é um dos pares, de um colega que não é amigo.

Esta espécie de violência autorizada entre amigos nos parece relevante porque no começo das oficinas os jovens parecem abafar o sofrimento causado pela violência "sutil" entre amigos. As falas dos jovens podem nos conduzir a acreditar na ausência de mágoa diante das brincadeiras ultrajantes - quando na realidade a ausência de reações explícitas pode encobrir raiva e ressentimento. Este ponto é de fundamental importância porque mostra uma das formas pelas quais a violência vai se entrelaçando às trocas mais cotidianas das relações entre pares. Acreditamos que há, sim, um incômodo latente provocado pela experiência cotidiana de uma violência "sutil" que vai endurecendo as relações, fazendo os estudantes se acostumarem ao que está aparentemente dado, e contribuindo para que os jovens não reajam imediatamente. É como se tivessem que se conformar com um cotidiano sofrível de relações em que, talvez, o medo de reagir oculta o medo maior de não pertencerem ao grupo.

\subsection{Violência e normas de convivência em grupo: inclusão, proteção e revanchismo}

Os jovens avaliaram que os grupos de pares usam da violência sob diferentes circunstâncias. Neste eixo analítico, destacamos que os jovens não se limitaram à análise das expressões "sutis" de violência. Eles reconheceram que violências explícitas são comuns na sua experiência escolar. "É isso aí. Esse é o nosso dia a dia", comentaram alguns da escola pública.

De acordo com os jovens, os episódios de violência mais frequentes estão relacionados a conflitos entre diferentes grupos de pares. Por isso consideramos a violência entre jovens na escola como intimamente ligada às relações que os grupos de pares estabelecem entre si. E mais: a violência aparece como uma resposta à tensão entre grupos, sendo um dos capítulos de uma relação conflituosa. Por isso, acreditamos que um episódio violento - explicitamente ou não - acaba por reproduzir a maneira como os grupinhos vêm se relacionando: resolvendo seus problemas com violência e tentando se impor um sobre o outro. Segundo os jovens, isso ocorre porque há um revanchismo contínuo entre os estudantes que perpetua a produção dos episódios violentos no ambiente escolar.

Até porque tem uma coisa muito assim:quando você tá com seus colegas e é zoado, tem tipo assim, eles ficam, "você não vai fazer nada?", "não vai tomar uma postura?". Então, tem meio que esse lance de uma zoação puxar a outra e a pessoa sente a necessidade de continuar, né? Aí a pessoa vai pensar assim: "será que eu não teria de parar com isso?", mas aí seu grupo tá dizendo que é pra você não deixar barato [...] (Alan, estudante da escola particular, 15 anos).

$\mathrm{Na}$ fala de Alan e de outros participantes da pesquisa, percebemos que eles percebem o grupo como incentivador de represália com novos episódios de violência. A reprodução das relações violentas seria uma forma de o grupo se 
fazer respeitar diante do outro, refazendo-se do aviltamento sofrido por um de seus componentes. Segundo os jovens, sempre haverá revanchismos entre grupinhos da escola porque "o grupo é feito uma mãe: não vai deixar você chegar apanhado em casa! Vai dizer pra você ir lá e bater também” (Alex, estudante da escola pública, 16 anos). O revanchismo é necessário como forma de reparação da imagem do indivíduo e do seu grupo.

Para os jovens participantes, a produção de atos de violência entre grupos diferentes ajuda a manter o jovem incluído no grupo, visto que ele compartilha da norma de convivência grupal; algo do tipo "você é do nosso grupo desde que faça as mesmas coisas que nós". A partir daí avaliamos que a inclusão e a permanência dos jovens nos grupos de amigos se dariam eminentemente por meio da adoção das mesmas normas de conduta. Seria o caso, então, de reconhecer a violência explícita como um dos elementos que está entrelaçado às normas de convivência dos grupos de pares? Provavelmente, existam elementos relevantes para os códigos grupais. Por exemplo: compartilhar hábitos parecidos, estilos de vida semelhantes, práticas de consumo etc. No caso deste estudo, a violência ocupou papel central nos códigos dos grupinhos de amigos, como um comportamento a ser adotado por todos os integrantes do grupo de pares.

Além de incluir e manter o jovem no grupo, a reprodução do revanchismo serviria também para protegê-lo das ameaças e violências de outros grupos, sejam as violências físicas ou não.

É tipo assim, seu grupo tá batendo numa pessoa. Você não quer que, você não gosta que façam isso. Mas você acaba batendo na outra pessoa porque você tem medo de que se você não bater nela, isso vai acontecer com você. É um medo mesmo (Thiago, estudante da escola particular, 16 anos, grifo nosso).

A manutenção da violência entre grupos de pares serve como "estratégia de defesa" pela qual "zoar" o outro evita que eles sejam "zoados". Os jovens usaram como justificativa o fato de, com o revanchismo, passam a gozar da proteção do grupo e obter um ganho secundário. A dinâmica que usa a reprodução da violência como estratégia preventiva revela o cenário da escola como terreno onde a dominação acontece a partir do poder do mais forte. Parece-nos que para estes jovens as relações entre pares estão pautadas ainda na lógica da força, seja da força física, ou ainda da força do poder de infligir qualquer outro dano diante de seus iguais.

Nesse sentido, estas práticas grupais, tão entrelaçadas à violência, aproximam a imagem dos grupos de pares à imagem das facções - bandos ou grupos de indivíduos partidários de mesma causa que lutam militarmente em oposição a outros grupos. Disseram os jovens da escola pública: "a partir do momento que você faz parte de um grupo, você não pode sair porque você vai fazer rixa com os outros, então você não vai poder mais mudar, entendeu? " (Diego, estudante da escola pública, 17 anos). "? [...] O grupo é uma facção" (Daniel, estudante da escola pública, 16 anos). 
Estes e outros fatores nos levam a perceber que a maneira como os jovens convivem dentro da escola tem, cada vez mais, se aproximado da maneira como se relacionam fora daquele espaço. Quando os participantes falaram sobre as normas de convivência com seus pares no ambiente escolar, não apareceu nenhum fator, nenhuma característica, que se remetesse a alguma especificidade da instituição escola. Por mais que da escola se esperassem regras sólidas de convivência - normas que guiassem a convivência dentro da escola e fossem eficazes na construção de relações mais solidárias entre o corpo escolar, parece que elas não se fazem presentes entre os jovens, deixando este espaço ser ocupado pela lei do mais forte.

Diante da veemência da lei do mais forte, buscamos saber se os participantes reconhecem alguma possibilidade das relações entre grupos não se pautarem na violência, ou seja, se havia alguma forma de cessar a violência. Nas oficinas eles chegaram à conclusão que sim, sendo que tal possibilidade pareceu menos possível para os participantes da escola pública do que para os estudantes da escola particular. Além disso, o rompimento com esta forma de relação traz consequências para o jovem que, individualmente, toma tal decisão, e há um preço a ser pago. Romper a cadeia de violência custa ao jovem rescindir também sua adesão ao código do grupo e, por conseguinte, enfrentar o banimento - o que nesse caso é quase sinônimo de passar a ser "zoado" também. Na medida em que a violência na forma de "brincadeiras" compõe a relação entre os grupos - e também intragrupo, visto que é critério de permanência para alguns deles, quebrar o ciclo implica quase sempre em ser excluído do grupo e passar a ser alvo de "zoação", desrespeito, violência.

Apesar de avaliarem que rescindir esse tipo de relação seria o posicionamento mais correto, o ônus decorrente da decisão lhes pareceu oneroso demais. "Não é fácil assim sair de justiceiro da história para ser mais um alvo" (Rodrigo, estudante da escola particular, 15 anos). E tornar-se mais um alvo, lembramos, significa estar por si mesmo no ambiente escolar, não ter a quem apelar defesa ou apoio em momentos de conflito. Significa perder proteção, e também, o reconhecimento de seus colegas. Pelas experiências dos jovens envolvidos na pesquisa, o ódio do grupo se direciona não apenas aos jovens de outros grupos, mas principalmente aos integrantes que demonstram oposição interna, manifestando algum distanciamento dos códigos e regras do grupo.

Para lidar com a violência que ocorre no ambiente escolar os jovens apostaram em saídas que são garantidas por eles mesmos ou, no máximo, por outro jovem que seja seu par. No elenco de possibilidades apresentadas pelos jovens, há de se ressaltar a ausência de quaisquer recursos externos ao próprio grupo. Os estudantes não fizeram referência aos professores, aos adultos, para lidar com os problemas da convivência. Houve ausência de referência às figuras de autoridade que deveriam representar simbolicamente a lei. Esta ausência é fato importante porque se remete a uma problemática da escola no contemporâneo: o fato de que embora a mesma se sustente a partir de um imaginário social de formação, e de responsabilidade dos adultos sobre as crianças, está cada vez mais em crise quanto à possibilidade de realmente dar conta da formação das gerações mais novas. "Este lugar [de sustentação das regras] cabe ao adulto, responsável perante a escola e a sociedade. Somente ele tem a medida da distância que faz a diferença 
entre professor e alunos, entre formadores e formados" (COLOMBIER; MANGEL; PERDRIALUT, 1989, p. 90 apud ANDRADE, 2003, p. 62, complemento do autor). Para nós, se trata de tomar este aspecto como analisador da relação dos estudantes com as figuras de autoridade da instituição escola - como exploramos com detalhes daqui para frente.

\subsection{Violência entre pares versus regras da escola: entre negligência e criminalização}

Durante o período de permanência nas duas escolas, não presenciamos qualquer intervenção dos professores e da direção/coordenação sobre as violências "sutis" entre pares. Apelidos, "brincadeiras" e determinadas formas de tratamento não produziram reação por parte dos educadores. Citações do tipo "Sua tapada, a gente tem que começar!", "Seu nego safado!" ocorriam com frequência entre os estudantes.

Os jovens participantes da pesquisa percebem a pouca atenção dos adultos em relação às expressões "sutis" de violência. Eles disseram que os professores e a coordenação/direção não fazem nada diante dessas violências e "esperam algum aluno aqui sair na porrada pra ver se vai fazer alguma coisa; isso quando faz alguma coisa, né?", disse um dos estudantes da escola pública. Apesar de perceberem a ausência de intervenção dos adultos, os jovens afirmaram com veemência que os educadores têm um papel importante, ou, deveriam ter um papel na busca da resolução das tensões, discussões e brigas que ocorrem entre os estudantes. Na opinião deles é atribuição da direção/coordenação interferir sobre conflitos que ocorrem entre grupos de pares.

Por mais que existam hoje críticas à escola e que percebamos um discurso generalizado de que a instituição escola estaria falida na sua missão educativa mais ampla, os jovens parecem reiterar a promessa de que cabe à escola cuidar das sociabilidades juvenis. Esta expectativa expressa, a nosso ver, uma demanda aos adultos de interferir sobre os conflitos envolvendo alunos. Provavelmente, por mais que não acreditem na eficácia das ações dos professores, como veremos a seguir, os alunos acabam reforçando o lugar de educador atribuído aos professores. Todavia, para além da simples repetição de um discurso, acreditamos que se trata realmente de reconhecer a importância da atuação da geração mais velha na mediação dos conflitos entre os mais jovens, buscando principalmente a construção de valores éticos por parte dos estudantes. Parece-nos que os jovens participantes da pesquisa estão de algum modo convocando os mais velhos a ajudá-los diante das dificuldades da relação intra- e intergrupal, e, sobretudo, na compreensão, por exemplo, de por quê tanta violência.

Perguntamos aos estudantes quais seriam, mesmo que raras, as ações efetuadas pelos educadores. Eles disseram que no geral os professores têm se limitado a remeter os problemas à direção/coordenação da escola. Na opinião deles, os professores têm feito pouco a respeito das tensões entre pares e acabam sempre "levando o caso para a direção". Além do mais, as falas dos estudantes se referiram exclusivamente à intervenção dos educadores sobre episódios de violência 
física, como brigas entre grupinhos. Por mais que o assunto em pauta fosse as formas "sutis" de violência, os jovens mencionaram exclusivamente ações que os adultos executam sobre violências físicas.

Temos então um cenário no qual a direção tem sido a principal instância para onde professores e alunos enviam suas considerações sobre o que vai mal na escola, seja os professores denunciando brigas entre alunos, ou estes reclamando de alguma dificuldade no funcionamento da escola. Quando há problemas a resolver, a direção é chamada pelo seu lugar de autoridade, de forma a tomar cabo da situação e encaminhar alguma resolução.

Uma vez na direção/coordenação da escola, os estudantes relatam que as medidas mais aplicadas aos casos de violência entre pares são: advertência, suspensão ou expulsão dos alunos envolvidos diretamente no caso, chamada dos pais de alunos para conversar com a direção/coordenação, separação de sala dos alunos envolvidos com objetivo de evitar novos episódios. Na visão deles, a direção/coordenação tem sido pouco eficaz em suas ações, e chegam mesmo a dizer que dificilmente ela conseguirá resolver completamente tais questões. Para eles a direção/coordenação não vai conseguir nunca resolver completamente os conflitos entre pares, podendo apenas amenizá-los, diminuir as tensões com o objetivo de que elas não eclodam em violências explícitas - agressões físicas. "Interferir sim, com certeza!", "Eu acho que cabe sim à coordenação fazer alguma coisa", "Mas nunca vai resolver", "Pode amenizar só", disseram. Alguns participantes, principalmente da escola pública, chegaram a demonstrar descrença dizendo que "A paz não existe", ou "A paz só existe no convento ou no céu"; o que demonstra o completo descrédito da justiça e da lei, tão comum em um contexto de cultura da violência (COSTA, 1988).

Os jovens dizem que a gestão da escola tem postura "frouxa" e que a figura da direção/coordenação tem de fazer valer seu lugar de autoridade perante os alunos. Sendo assim, os jovens sinalizam nas entrelinhas do discurso a necessidade de haver algum suporte simbólico, uma referência que seja efetiva para os mais novos e guie os moldes de relações dentro da escola. Alguém que consiga impor limite aos comportamentos agressivos, e restaure a premência de exercitarmos relações mais éticas no ambiente escolar. Percebemos portanto que, quando estimulados, os estudantes propõem um encaminhamento para a relação adulto-jovem como saída possível para superar as dificuldades da convivência entre eles. A reconstrução de relação de respeito dos alunos para com a direção/coordenação seria a condição primeira para que ela obtivesse mais sucesso nas tentativas de cessar a violência escolar, de maneira específica, e de educar as novas gerações, de maneira mais ampla.

Para eles, apenas quando o diálogo não for mais eficaz a direção/coordenação deveria adotar as punições das advertências, suspensões, expulsão, chamar os pais ou separar os alunos de sala. Isso porque para eles "a punição é uma maneira mais rigorosa de resolver as coisas" (Duda, estudante da escola particular, quinze anos) e, portanto, não deveria ser a primeira medida a ser adotada. 
Os estudantes da escola pública indicaram ainda um aspecto importante a respeito das formas de resolução dos conflitos entre pares. Como vimos anteriormente, eles se queixaram que a direção da escola não vem agindo sobre esses episódios de violência nem mesmo sobre os episódios mais explícitos. Nesse momento é que a experiência deste grupo se diferenciou radicalmente da experiência relatada pelos estudantes da escola particular. Os jovens da escola pública relatam que é muito comum que as diretoras encaminhem os casos de violência na escola para a delegacia, seja entre pares, ou qualquer outro tipo de violência. Os alunos foram enfáticos: sabem que este encaminhamento ocorre com muita frequência nas escolas públicas e, ao mesmo tempo, avaliam que isso não acontece especificamente na escola deles porque a diretora "não leva a sério" os problemas deles.

Para os alunos da escola pública, então, caso de briga na escola é caso de polícia. Para eles não há propriamente uma crítica ao fato de as diretoras de outras escolas públicas entregarem os casos de conflitos na escola aos delegados. Este processo parece operar como um tipo de criminalização dos conflitos escolares que se concretiza não apenas com o procedimento da direção encaminhar os conflitos escolares à delegacia, mas também na maneira como a comunidade escolar encara as tensões que ali ocorrem, e que são produzidas. Ao tomar essa posição, a direção se desresponsabiliza, e ao mesmo tempo, estimula que demais atores da comunidade escolar, incluindo professores e alunos, façam o mesmo movimento.

Além disso, com esta medida a direção mostra, implicitamente, que a Lei emerge do contexto policial; ou melhor, a direção mostra que ela não ocupa tal lugar e a Lei só consegue se fazer valer a partir de um contexto de força física e dominação. ${ }^{2}$ Entregar a resolução dos conflitos e brigas escolares para a força policial parece ser uma forma de a direção atestar o fenecimento do seu papel de autoridade simbólica perante os mais jovens.

Neste contexto, fica mais fácil compreender porque os participantes da pesquisa falaram que os conflitos escolares nunca serão resolvidos: o procedimento dos educadores contribui para que os alunos tenham a percepção de que pouco ou nada se pode fazer para o enfrentamento da violência. A negligência da parte dos professores, e o estímulo à criminalização de parte dos diretores, faz a ação dos adultos parecer inócua - principalmente porque, recorrendo à polícia se pode até "suprimir" a violência com procedimentos de contenção, mas nunca compreendê-los.

\section{Considerações finais}

O trabalho de campo indicou que alguns apelidos e formas grosseiras de tratamento se manifestam na escola como formas "sutis" de violência que se ocultam sob a forma de brincadeira ou "zoação". As "brincadeiras" violentas parecem divertir os jovens, apimentando a convivência. E mais, a intensidade da diversão é incrementada quando o outro parece submetido, aviltado, e há a impressão de controle sobre ele. 
Chegamos à conclusão de que a convivência no grupo de pares tem oportunizado aos estudantes a construção de um discurso legitimador da violência. A sutileza destas violências não se refere apenas à ausência do uso da força física, mas também à facilidade com que passam a permear a convivência, tornando-se tão comuns que são tomadas como "naturais". Para os jovens estudantes, os grupos de amigos com os quais eles mais convivem costumam aceitar, concordar e/ou incentivar respostas violentas para os conflitos que ocorrem na escola. As "pequenas leis" dos grupinhos contemplam estes episódios, seja para as relações dentro do grupo, ou deste com outros grupinhos da escola.

Parece-nos que as normas de convivência nos grupos - inserção, permanência e conduta - são referências muito fortes, e às vezes determinantes, para guiar os jovens na vivência da escola, pois as regras do grupo de pares são a lei a que os jovens dão mais respaldo e à qual estão mais submetidos. Permanece no grupo quem age como o grupo determina. No fim das contas a composição do grupo parece se definir a partir de certa homogeneidade no comportamento dos jovens; o que colabora para constituí-los como iguais. Tratar-se-ia então de um grupo de pares enquanto grupo de iguais, iguais não no sentido da hierarquia - de que estão todos em posição de horizontalidade - mas no da homogeneidade da composição do grupo.

Assim, induz-se que o outro para estes jovens é no máximo igual a eles mesmos. Isso minimiza as possibilidades do jovem ter de se confrontar com as diferenças. O que nos parece em aberto é a necessidade de aprofundar a seguinte questão: as vivências grupais estariam fazendo com que os jovens evitem as experiências reais de alteridade - pois suas trocas são eminentemente com seus pares - ou, ao contrário, a violência intra e intergrupos seria justamente uma forma de reconhecer a presença do outro, mesmo que via agressão?

A instituição escola, na figura dos adultos educadores, ao negar seu papel de se haver com as sociabilidades juvenis, se afasta da sua missão de formação das gerações mais novas. Pelo que nos parece, está contribuindo para oferecer aos jovens condições de subjetivação onde as diferenças são alvo de violência: seja pelo afastamento do outro ao se recusar a convivência com ele; ou, paradoxalmente, pelo controle e manipulação da diferença por meio de violências "sutis", que também conduzem a minimizar o estranhamento que a alteridade provoca.

\section{Notas}

${ }^{1}$ Nome fictício. Todos os nomes usados para identificar os jovens neste artigo são fictícios com o intuito de preservar anônima a identidade dos participantes.

${ }^{2}$ Caso emblemático ocorreu em janeiro de 2014 no estado de Goiás, onde a administração de várias escolas públicas seria entregue à polícia militar. 


\section{REFERÊNCIAS}

ALEXANDRE, I. J. Relações raciais: o explícito e o implícito nas interações entre alunos em uma escola pública. 2006. 132 f. Dissertação (Mestrado em Educação)-Instituto de Educação, Universidade Federal de Mato Grosso, Cuiabá, 2006.

ANDRADE, F. C. B. de. Considerações psicanalíticas sobre a violência na escola. Aprender: Cad. de Filosofia e Psic. da Educação, Vitória da Conquista, ano I, n. 1, p. 57-66, 2003.

BARUS-MICHEL, J. A Violência complexa, paradoxal e multivoca. In: SOUZA, M. de; MARTINS, F. M. M. C.; ARAUJO, J. N. G. de. (Org.). Dimensões da violência: conhecimento, subjetividade e sofrimento psíquico. São Paulo: Casa do Psicólogo, 2011. p. 19-34.

BIRMAN, J. Cadernos sobre o mal. Rio de Janeiro: Record, 2009.

BLEGER, J. Grupos operativos no ensino. In: . Temas em Psicologia. São Paulo: Martins Fontes, 1980. p. 53-82.

BOURDIEU, P. O poder simbólico. Rio de Janeiro: Bertrand Brasil, 2001.

BRINGIOTTI, M. I.; KRYNVENIUK, M.; LASSO, S. Las multiples violencias de la "violencia" en la escuela: desarrollo de un enfoque teorico y metodologico integrativo. Paidéia, [S.1.], v. 14, n. 29, p. 313-325, set./dez. 2004.

CAMACHO, L. M. Y. As sutilezas das faces da violência nas práticas escolares de adolescentes. Educação e Pesquisa, [S.1.], v. 27, n. 1, p. 123-140, jan./jun. 2001.

CAMACHO, L. M. Y.; BELTRAME, S. A. B. Usos e abusos da etnografia na educação. Revista reflexão e Ação, [S.1.], v. 5, n. 2, 1999.

CAMPOS, P. H. F., CAMPOS, D. T. F. Fetichização e banalização da violência: a clivagem do eu e a "foraclusão" do sujeito. In: SOUZA, M. de; MARTINS, F. M. M. C.; ARAUJO, J. N. G. de. (Org.). Dimensões da violência: conhecimento, subjetividade e sofrimento psíquico. São Paulo: Casa do Psicólogo, 2011. p. 129150 .

CAON, J. L. Mais perigosas são as feridas que não doem, não ardem nem sangram. In: HARTMANN, F.; ROSA JR., N. C. dal F. da (Org.). Violência e contemporaneidade. Porto Alegre: Artes e Ofícios, 2005. p. 99-116. 
CHARLOT, B. A violência na escola: como os sociólogos franceses abordam essa questão. Sociologias, [S.1.], v. 4, n. 8, p. 432-443, jul./dez. 2002.

COSTA, J. F. Violência e psicanálise. Rio de Janeiro: Graal, 1986.

COSTA, J. F. Narcisismo em tempos sombrios. In: BIRMAN, J. (Org.). Percursos na História da Psicanálise. Rio de Janeiro: Taurus, 1988. p. 151-174.

COUTINHO, L. G. Adolescência e errância: destinos do laço social no contemporâneo. Rio de Janeiro: NAU / FAPERJ, 2009.

DAYRELL, J. et al. Juventude e Escola. In: SPOSITO, M. P. (Coord.). Estado da Arte sobre juventude e escola na pós-graduação brasileira: educação, ciências sociais e serviço social (1999-2006). Belo Horizonte: Argvmentvm, 2009. v. 1, p. $57-125$.

DEBARBIEUX, E. A violência da escola francesa: 30 anos de construção social do objeto (1967-1997). Educação e Pesquisa, [S.1.], v. 27, n. 1, p. 163-193, jan./ jun. 2001.

FAGUNDES, J. O. A psicanálise diante da violência. In: SANDLER, P. C. (Org.). Leituras psicanalíticas da violência. São Paulo: Casa do Psicólogo, 2004. p. 2140. Coleção psicanálise clínica, sociedade.

FAZZI, R. C. O drama racial de crianças brasileiras: socialização entre pares e preconceito. Belo Horizonte: Autêntica, 2004.

GURSKI, R. Violência juvenil e laço social contemporâneo. Educação e Realidade, [S.1.], v. 37, n. 1, p. 233-249, jan./abr. 2012.

HOGEVEEN, B. R. Youth (and) Violence. Sociology Compass, [S.1.], v. 1, n. 2, p. 463-484, 2007.

KEHL, M. R. (Org.). A função fraterna. Rio de Janeiro: RelumeDumará, 2000.

LEVISKY, D. L. Adolescência e violência. São Paulo: Casa do Psicólogo, 2000.

MARIN, I. da S. K. Sofrimento e violência na contemporaneidade: destinos subjetivos. In: KHOURI, M. G. et al. (Org.). Leituras Psicanaliticas da Violência. São Paulo: Casa do Psicólogo, 2004. p. 85-100.

MARRA, C. A. dos S. Violência escolar: a percepção dos atores escolares e a repercussão no cotidiano da escola. São Paulo: Annablume, 2007. 
MARTINS, J. B. Observação participante: uma abordagem metodológica para a psicologia escolar. Semina: Ci. Soc./Hum, [S.1.], v. 17, n. 3, p. 266-273, 2005.

PINO, A. Violência, educação e sociedade: um olhar sobre o Brasil contemporâneo. Educ. Soci., [S.1.], v. 28, n. 100, p. 763-785, out. 2007.

SOUZA, M. L. R. de. Violência. São Paulo: Casa do Psicólogo, 2005. Coleção Clínica Psicanalítica.

SPOSITO, M. P.; TOMMASI, L. de; MORENO, G. G. Adolescentes em processo de exclusão social. In: SPOSITO, M. P. (Coord.). Estado da Arte sobre juventude e escola na pós-graduação brasileira: educação, ciências sociais e serviço social (1999-2006). Belo Horizonte: Argvmentvm, 2009. v. 1, p. 127-178.

STELKO-PEREIRA, A. L.; WILLIAMS, L. C. de A. Reflexões sobre o conceito de violência escolar e a busca por uma definição abrangente. Temas em Psicologia, [S.1.], v. 18, n. 1, p. 45-56, 2010.

Recebido em: 18 de outubro de 2013

Aceito em: 30 de junho de 2014 